\title{
Immunohistological studies of lymphoproliferative lesions in a fatal case of Epstein-Barr virus infection
}

\author{
P MORGAN-CAPNER,* J A MORRIS, $\dagger$ M B MCILLMURRAY, J A THOMAS,§ \\ D H CRAWFORD, $\uparrow$ T AZIM\|
}

\begin{abstract}
From the *Department of Virology, Preston Infirmary, Preston, the †Department of Pathology, Lancaster Moor Hospital, Lancaster, the $\ddagger$ Department of Medicine, Royal Lancaster Infirmary, Lancaster, the §Histopathology Unit, Royal College of Surgeons, Imperial Cancer Research Fund, London, the $\$$ Department of Virology, Royal Postgraduate Medical School, London, and the \|Department of Haematology, Faculty of Clinical Sciences, University College, London
\end{abstract}

SUMMARY A fatal case of infectious mononucleosis occurred in a young adult. Abnormal serological features were noted in his mother, although there was no other family history suggesting an inherited defect of immune response to Epstein-Barr virus (EBV). The cellular infiltrate observed in tissues obtained at necropsy was analysed with a range of specific monoclonal and polyclonal antibodies.

Polyclonal plasmacytoid B cell proliferation had occurred in many tissues. These cells were positive for EBV nuclear antigen, but viral particles were not seen on ultrastructural examination, and the virus was not isolated, suggesting a non-permissive infection.

Infectious mononucleosis is a consequence of primary infection with Epstein-Barr virus (EBV). Spontaneous recovery usually occurs, and fatal infectious mononucleosis is uncommon. Fatal lymphoproliferative diseases associated with infectious mononucleosis can develop spontaneously in previously healthy subjects with no overt family history of the disease. ${ }^{1}$ EBV infection occurring in young related men with $X$-linked lymphoproliferative syndrome (XLPS), however, usually manifests as a fatal inability to mount an adequate immune response, resulting in a rapid progressive polyclonal B cell proliferation, aplastic anaemia, or hypogammaglobulinaemia. ${ }^{1-3}$ In the United Kingdom only one family with XLPS has been identified; death from fulminant EBV infection having occurred in two male siblings.

We report a case of fatal infectious mononucleosis in a previously fit young man. Although the family history was unremarkable, the mother showed abnormal EBV specific serology, suggesting an inheritable immunological defect specific for EBV. The availability of specific monoclonal antibodies also permitted a detailed immunohistological analysis of the cellular infiltrate of tissue samples obtained at necropsy.

\section{Case report}

A 16 year old boy was admitted with a two day history of progressive difficulty with breathing. He had been febrile with a sore throat for two weeks, and infectious mononucleosis had been diagnosed by the general practitioner as serology had shown a positive differential slide test (IM absorption kit, Mercia Diagnostics, West Byfleet) for heterophil antibody. The only medical history of note was uncomplicated mumps meningoencephalitis at 5 years of age from which he had made a full recovery.

On admission to hospital he was febrile $\left(39^{\circ} \mathrm{C}\right)$ and dyspnoeic. His difficulty with breathing was attributed to grossly enlarged tonsils. Cervical and supraclavicular lymphadenopathy were present, but inguinal and axillary lymph nodes, liver, and spleen were impalpable. A generalised macular rash was present. Laboratory tests showed a haemoglobin concentration of $14.0 \mathrm{~g} / \mathrm{dl}$ and a leucocyte count of $8.5 \times$ $10^{9} / 1$. The lymphocyte count, however, was only 1.6 $\times 10^{9} / 1$, and atypical cells were not observed. The differential slide test for heterophil antibody was still positive. The only abnormalities on biochemical screening were a lowered plasma sodium concentration of $120 \mathrm{mmol} / \mathrm{l}$ (normal range 135-144) attributed to excessive sweating and a negative sodium balance, an increased aspartate transaminase activity of $57 \mathrm{U} / 1$ (normal <40), and alkaline 
phosphatase activity of $103 \mathrm{U} / 1$ (normal <48). Candida albicans was isolated from a throat swab, but bacterial and mycological cultures of various other sites did not indicate any more likely pathogens. Treatment was started with oral prednisolone $(40 \mathrm{mg}$ twice daily) and nystatin mouth washes.

Seven days later his dyspnoea worsened with the development of stridor and cyanosis. Tracheotomy was performed to relieve the upper respiratory tract obstruction and positive pressure ventilation started. Improvement was not dramatic. Tachypnoea continued, and two days later multiple opacities were observed on chest $x$ ray. His lung fields had previously been clear. Bronchoscopy showed inflamed bronchial mucosa and a white exudate throughout. A lung biopsy specimen showed non-specific pneumonitis with chronic inflammatory changes and no evidence of opportunistic infection. Treatment was changed to $200 \mathrm{~g}$ intravenous hydrocortisone every four hours. Bacterial culture of sputum showed a mixed flora, and he was given broad spectrum antibiotics. His condition, however, continued to deteriorate with the onset of gastrointestinal bleeding as a consequence of disseminated intravascular coagulation, prothrombin time 41 seconds (control 15); partial thromboplastin time 74 seconds (control 41); fibrinogen $0.74 \mathrm{~g} / 1$ (normal 2-4); fibrinogen degradation products $20 \mathrm{mg} / \mathrm{l}$; platelets $52 \times 10^{9} / \mathrm{l}$ ). Although septicaemia was suspected, blood cultures yielded negative results. His liver function had deteriorated (bilirubin $75 \mathrm{mmol} / \mathrm{l}$, normal $<15$ ), aspartate transaminase activity $3680 \mathrm{U} / \mathrm{l}$, alkaline phosphatase activity $113 \mathrm{U} / \mathrm{l}$; and acute renal failure developed, urea $18 \cdot 1 \mathrm{mmol} / 1$ (normal $2 \cdot 5-6 \cdot 7$ ), creatinine concentration $276 \mu \mathrm{mol} / 1$ (normal $<120$ ). Despite appropriate supportive treatment he died 17 days after admission.

Serum taken three days before death and four weeks after the onset of his illness had an EBV viral capsid antigen IgG titre of 128 and viral capsid antigen IgM titre of 8 . Antibodies to EBV nuclear antigen were present at a titre of 4 , but antibodies to early antigen were not detected.

\section{FAMILY STUDIES}

The patient was the only child of his mother's second marriage. She had had a son and daughter by her first marriage. This daughter had two children, one of whom was male. All four were well, were positive for EBV viral capsid antigen antibodies, and had titres in the normal range (8-500) with no detectable early antigen antibody. Although the mother's viral capsid antigen and anti-EB nuclear antigen titres (64 and 10, respectively) were not increased, she had detectable early antigen antibodies (titre 16) in two samples taken at an interval of six months. Questioning of the mother showed that there had been no early deaths in the previous three generations of her family and that her two brothers were alive and well.

\section{NECROPSY FINDINGS}

The necropsy was performed 21 hours after death There was gross enlargement of lymph nodes in all lymphatic fields, the largest lymph node weighing $20 \mathrm{~g}$. There was severe inflammation, ulceration, and oedema of the mucosa of the upper respiratory tract, trachea, and bronchi. The lungs were congested and oedematous. Furthermore, there were multiple nodules up to $1 \mathrm{~cm}$ diameter distributed throughout both lungs (fig 1). The stomach and small intestine were dilated and contained relatively fresh blood in the lumina. There were acute erosions of the gastric mucosa. The liver was grossly enlarged weighing $2900 \mathrm{~g}$, and on section showed multiple areas of haemorrhage. The spleen weighed $500 \mathrm{~g}$. The kidneys were swollen and there was mild cerebral oedema. Specimens of all body organs were fixed in formalin, gluteraldehyde, snap frozen in liquid nitrogen, placed in tissue culture medium and used to prepare imprints.

\section{HISTOPATHOLOGY}

Conventional histological sections of formalin fixed tissue from all body organs were examined. The lymph nodes showed extensive necrosis together witho a diffuse infiltrate of immunoblastic and more mature? plasmacytoid cells. A similar mixture of morphologically primitive and more mature lymphoid cells was diffusely distributed in the respiratory tract mucosa and spleen and formed the multiple lung nod-

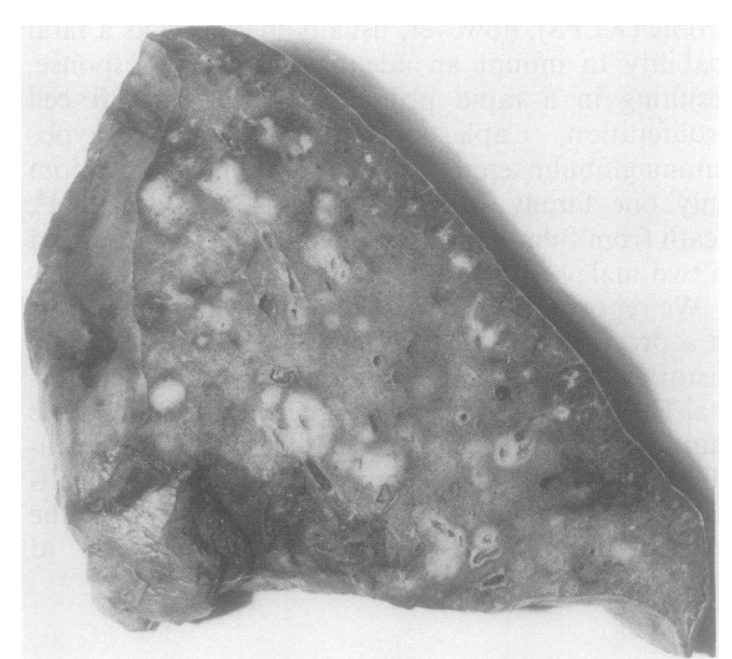

Fig 1 Lung containing multiple white nodules. 


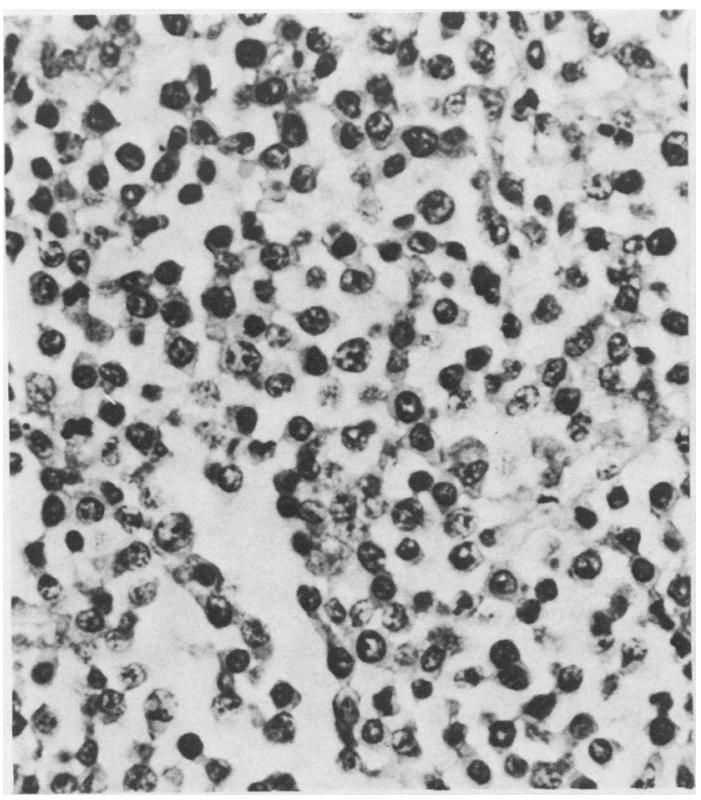

Fig 2 Lung nodule; diffuse infiltrate of plasmacytoid lymphocytes. $\times 370$.

ules (fig 2). The liver parenchyma was largely replaced by a dense lymphoid infiltrate around the portal tracts and areas of necrosis around the efferent venules.

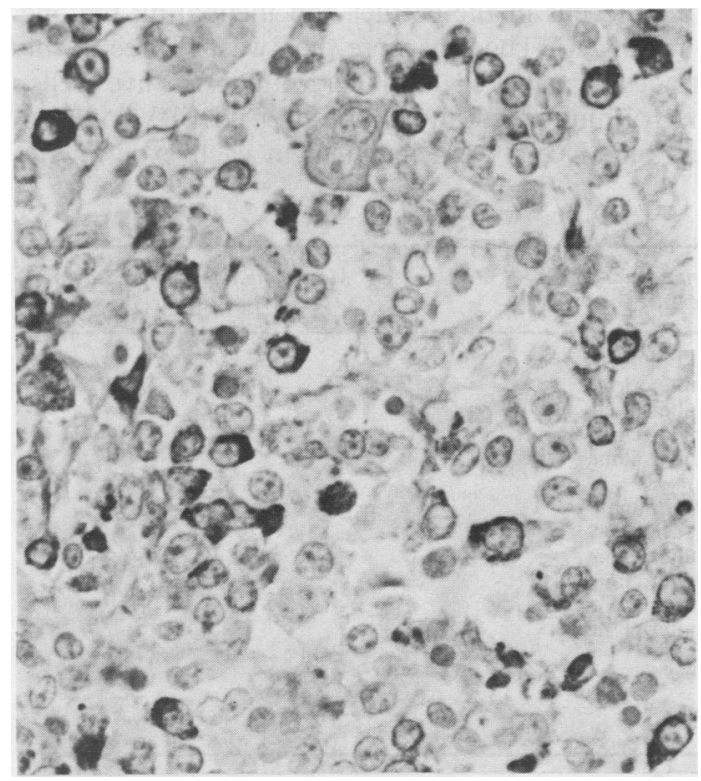

Fig 3 Diffuse infiltrate of immunoblasts and plasmacytoid cells in the liver. There is strong intracytoplasmic staining for IgA. (Immunoperoxidase.) $\times 370$.
ELECTRON MICROSCOPY

Ultrastructural examination of the liver, lung nodules, and lymph nodes showed rather poor preservation of cellular detail due to post mortem autolysis. The lymphoid cells were recognisable, however, as immunoblasts and plasmablasts. The immunoblasts had large vesicular nuclei with prominent central nucleoli but no discernible cytoplasmic differentiation. The plasmablasts showed some peripheral nuclear chromatin condensation and strands of rough endoplasmic reticulum in the cytoplasm. A prolonged search failed to indicate viral particles.

\section{IMMUNOHISTOLOGY}

Immunohistological staining of formalin fixed material using a conventional indirect immunoperoxidase technique and optimal dilutions of antisera to $\operatorname{IgG}, \operatorname{IgA}$, IgM and $\kappa$ and $\lambda$ light chains showed that the lymphoid infiltrate in lymph nodes, spleen, liver, respiratory tract mucosa and lung was a polyclonal proliferation of B lymphocytes. There was strong intracytoplasmic staining for IgG, IgA, and IgM without light chain restriction in a proportion of cells in all sections (fig 3).

Cryostat sections of frozen tissues were examined for Epstein-Barr nuclear antigen using the anticomplement immunoperoxidase test. $^{5}$ With the exception of brain, kidney, and heart, all tissue samples contained diffuse populations of large cells that were EB nuclear antigen positive (fig 4).

Cryostat sections were also examined with a panel of monoclonal antibodies (table) to lymphocyte markers using the alkaline phosphatase-antialkaline phosphatase method. ${ }^{9}$ In addition to cytoplasmic immunoglobulin, the EB nuclear antigen positive cells showed weak staining with monoclonal antibodies PD7 and B4, strong staining for T10, and class II (HLA-DR) antigens and were unreactive with all other specific $B$ and $T$ cells markers.

In lymph nodes and spleen the EB nuclear antigen positive cell infiltrates were accompanied by moderate numbers of phenotypically mature T cells $(\mathrm{CD} 2$ positive, CD3 positive) mainly of inducer/helper (CD4 positive) type. Class II antigens were expressed on many of these cells as well as on numerous dendritic cells and macrophages. Similar cell populations were also shown in the lung.

In the liver widespread centrilobular necrosis had occurred. The pronounced periportal lymphoid infiltrates also consisted of numerous EB nuclear antigen positive cells with moderate numbers of inducer T cells. Kupffer cells expressed class II antigens, but these were not shown on hepatocytes. Class I (HLA-ABC) antigens were present on all cells. No lymphoproliferative infiltrates were detected in the 


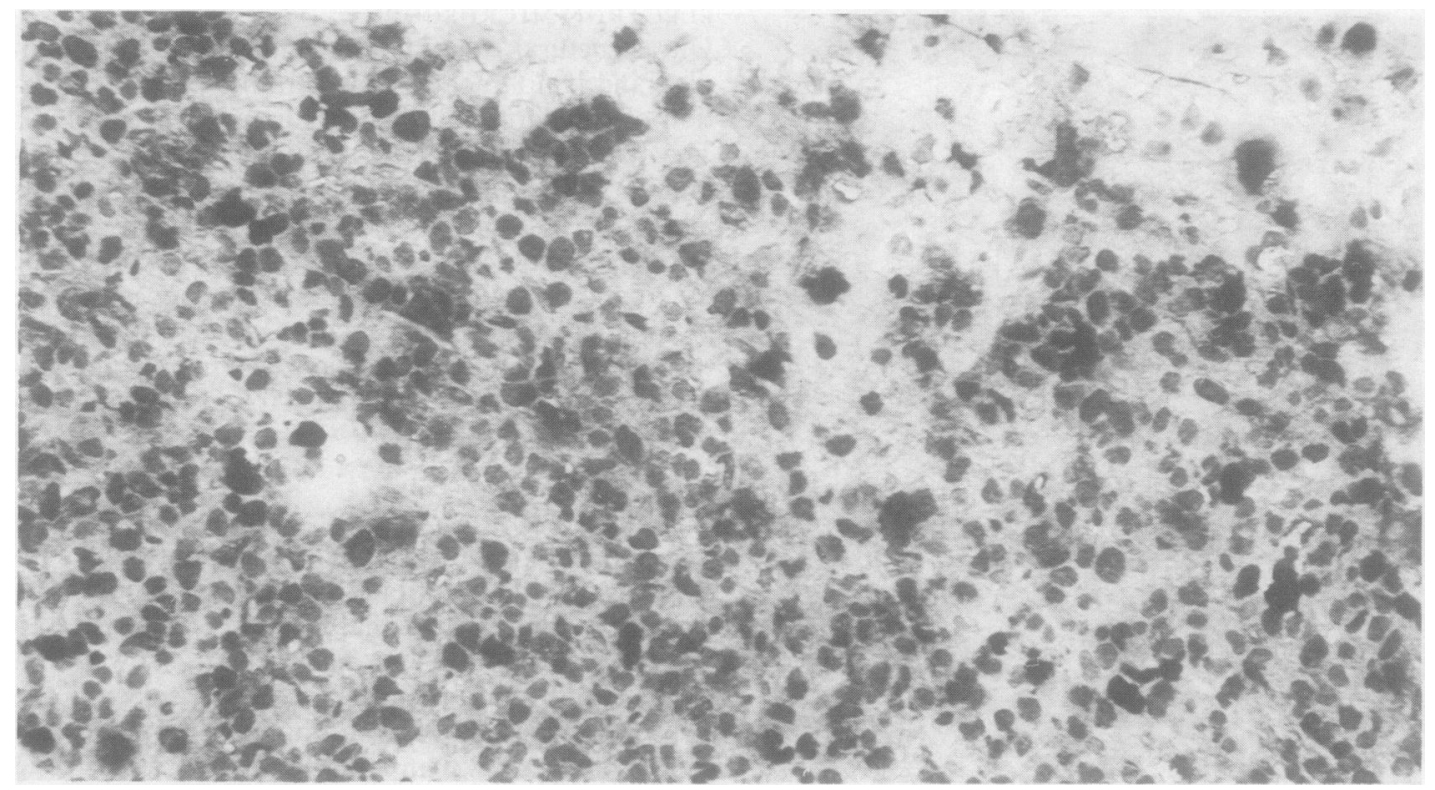

Fig 4 Cryostat section of liver stained for EB nuclear antigen ( $A C I P x)$. Periportal lymphoid infiltrate contains numerous EB nuclear antigen positive cells. EB nuclear antigen positive cells are also present in some surrounding hepatic parenchyma. $\times 300$.

brain, heart, or kidney, although variable small numbers of perivascular inducer $\mathrm{T}$ cells were seen.

\section{VIRUS ISOLATION}

Necropsy tissue samples from thymus, spleen, lung, heart, liver, mediastinal lymph node, lung nodule, kidney and brain were minced in $1-2 \mathrm{ml}$ of sterile culture medium. The samples were frozen and thawed rapidly three times and then centrifuged at $2000 \mathrm{rpm}$ for 10 minutes to pellet the cell debris. The super- natant medium was filtered through a $0.45 \mu \mathrm{m}$ filter and stored at $-70^{\circ} \mathrm{C}$ as two $0.5 \mathrm{ml}$ aliquots

Tissue extracts from each tissue were used to infect two separate samples of mononuclear cells derived from umbilical cord blood by resuspending a pellet of $2 \times 10^{6}$ cells in the extract and incubating for one hour at $37^{\circ} \mathrm{C}$. The cells were then washed free of the extract and cultured in $200 \mu \mathrm{l}$ volumes in five wells. Control uninfected and B95-8 derived EBV infected cord blood cells were included in each experiment.

Table Reagents used for cryostat section immunohistology

\begin{tabular}{|c|c|c|c|}
\hline $\begin{array}{l}\text { Monoclonal antibody: } \\
\text { antigen defined }+ \text { (clone) }\end{array}$ & $\begin{array}{l}\text { Reaction on normal } \\
\text { cells }\end{array}$ & $\begin{array}{l}\text { Commercial source/ } \\
\text { reference }\end{array}$ & $\begin{array}{l}\text { Monoclonal antibodies staining } \\
\text { on EBNA positive cells }\end{array}$ \\
\hline 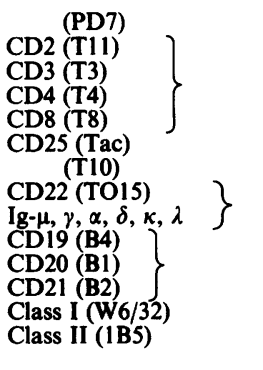 & $\begin{array}{l}\text { Most leucocytes } \\
\text { T cells and functional } \\
T \text { cell subsets } \\
\text { Activated } T \text { cells } \\
\text { Activated } \mathrm{T} \text { and B cells } \\
\text { B cells and plasma cells } \\
\text { B cell subsets } \\
\text { Most nucleated cells } \\
\text { B cells, activated T cells, } \\
\text { antigen presenting cells }\end{array}$ & $\begin{array}{l}\text { Dakopatts } \\
\text { Coulter clone } \\
\text { Coulter clone } \\
\text { Coulter clone } \\
\text { Coulter clone } \\
6 \\
\text { Orthomune } \\
\text { Dakopatts } \\
\text { Coulter clone } \\
\text { Coulter clone } \\
\text { Coulter clone } \\
\text { Coulter clone } \\
\text { Seralab } \\
7\end{array}$ & $\begin{array}{l} \pm \\
- \\
- \\
- \\
- \\
++ \\
+ \\
+ \\
- \\
\pm \\
+ \\
++\end{array}$ \\
\hline EB virus EA (K9-2) & - & $*$ & - \\
\hline
\end{tabular}

†CD $=$ cluster of differentiation nomenclature for human leucocyte antigens. ${ }^{8}$

Primary antibodies were labelled with rabbit antimouse Ig and monoclonal antibody alkaline phosphatase/antialkaline phosphatase conjugate (Dakopatts).

*Kindly supplied by Professor GR Pearson, Microbiology Department, Georgetown University Medical Center, Washington DC, 20007,USA. 
The cells were fed weekly and observed for eight weeks for signs of proliferation and transformation.

Although the control EBV infected cord blood cells from both samples showed transformed foci after two weeks, no sustained growth was seen in any of the other wells.

\section{Discussion}

The presenting clinical symptoms and serology in this previously healthy 16 year old boy were consistent with infectious mononucleosis, although atypical lymphocytes and a lymphocytosis were not observed; but he did rapidly succumb to respiratory, hepatic, and renal failure due to a widespread lymphoproliferative disease. Evidence for an overwhelming acute EBV infection was the presence of EBV specific IgM antibodies in the serum and EB nuclear antigen in the proliferating cells of various necropsy tissue specimens. This patient had apparently been able to withstand the usual childhood infections, which suggest that the defective immune response was specifically related to EBV.

The serological findings in this case showed some similarity to XLPS. These patients usually show specific IgM antibody responses to viral capsid antigen during the acute primary infection or high titre IgG antibodies to viral capsid antigen and early antigen indicative of a persistent EBV infection. Antibody titres to EB nuclear antigen are consistently absent or low. The failure to detect antibodies to early antigen in this case, however, is unexpected for XLPS. Furthemore, asymptomatic mothers of men affected by XLPS have serological evidence of continuous active infection, with raised IgG antibodies to both viral capsid antigen and early antigen. ${ }^{13}$ The patient's mother may possibly be a carrier of an immunological defect specific for EBV as her serology showed detectable titres of early antigen, suggesting a persistent poorly controlled EBV infection.

Several interesting features of the lymphoid infiltrates and accompanying morphologically normal cells were obtained by detailed immunohistological study of the necropsy samples. The EB nuclear antigen positive cells showed primitive morphology with vesicular nuclei and prominent nucleoli but were polyclonal with respect to both light $(\kappa+\lambda)$ and heavy (IgG, IgA, IgM) immunoglobulin chain expression. Using an extensive panel of monoclonal reagents to lymphocyte determinants, the cells were clearly unreactive with most specific $B$ and all mature $\mathrm{T}$ cell markers. Weak staining with monoclonal antibodies PD7 and B4, however, as well as strong staining for T10 and class II antigens is phenotypically consistent with an activated or transformed B cell. ${ }^{10}$ The heightened expression of class II antigens is con- sistent with similar observations in diffuse rapidly proliferating B cell disorders ${ }^{11}$ and has also been reported in a variety of non-lymphoid malignant conditions. ${ }^{5}$ Immune and recombinant interferon- $\gamma$ can induce or enhance the expression of class II antigens in vitro on lymphocytes, ${ }^{12}$ mesenchymal and epithelial cells, ${ }^{12}$ as well as on human tumour xenografts in vivo. ${ }^{13}$ This has important implications in the association between the control of MHC restricted immune response to viral infections and the potentiation of tumour growth.

There are now several reports of fatal EBV induced lymphoproliferative diseases developing in immunodeficient subjects. At risk are patients with primary immunodeficiency disease ${ }^{1314}$ or acquired immunosuppressed states following organ transplantation, ${ }^{1516}$ and, more recently, patients with the acquired immunodeficiency syndrome (AIDS). ${ }^{17}$ Sporadic cases of fatal sequelae to infectious mononucleosis in normal subjects, though rare, have been reported. ${ }^{1819}$ The tumours are characterised by strong morphological heterogeneity and exhibit a widespread extranodal distribution. The infiltrates are usually composed of large cells variously described as immunoblastic, lymphoplasmacytoid, or polymorphic in type. Until recently, these have always been considered to be polyclonal in origin on the basis of absent light chain restriction using immunocytochemical techniques. In view of the rapidly infiltrative nature of these lesions some controversy exists as to whether these lesions actually represent an exaggerated B cell hyperplasia or an autonomous outgrowth of atypical malignant cells transformed by the virus. Recent molecular hybridisation studies with cloned fragments of EBV-DNA have shown that the proliferating B cells in these patients are not replicating virus actively and therefore represent an early (non-lytic and non-permissive) stage of infection. ${ }^{20}$ This was supported by the absence of viral capsid antigen and early antigen on the EBV infected B cells in the circulation. In the present case early antigen, as defined by monoclonal antibody $\mathrm{K} 9 \cdot 2$, was not detected on the tumour cells (expression of viral capsid antigen was not investigated), and no virus particles were seen at electron microscopy. No transforming virus was extracted from the tissue, which contrasts with previous reports. ${ }^{18}$ This may therefore represent a subtype of the disease in which the infected B cells cannot support a lytic infection by the virus. An important clinical implication of this is that treatment with acyclovir may be beneficial with a lytic infection, ${ }^{1520}$ but latently infected cells are resistant.

Subsequent studies in patients with previously polyclonal tumours show that the lesions can progress to conventional type lymphomas with restricted light chain expression. Furthermore, in any 
one subject these tumours may be biclonal, expressing distinct Ig classes either at the same or different anatomical sites. ${ }^{14}$ Chromosomal rearrangements may also be used to establish the malignant nature of the tumour cells. ${ }^{21}$ The clonal origin of these tumours may ultimately be resolved by increasing diagnostic use of in situ hybridisation techniques with radiolabelled probes to detect Ig gene rearrangements. These techniques have been used effectively to detect monoclonal B cell lymphomas at presentation in cardiac transplant recipients ${ }^{20}$ and those evolving from polyclonally activated hyperplastic B cells following bone marrow transplantation in a patient with severe combined immunodeficiency. ${ }^{14}$

In the secondary lymphoid organs, despite effacement of normal $\mathbf{B}$ follicles by the infiltrating cells, $\mathrm{T}$ dependent areas were partially spared. In the spleen these foci, reminiscent of the periarteriolar lymphoid sheath, were predominantly composed of activated $T$ inducer cells (class II positive, CD4 positive), which nevertheless failed to express the specific CD25 activation marker. Similar inducer T cell populations also accompanied the hepatic infiltrates. It is impossible to know whether these cells were also predominant in the circulation. Normally, $T$ suppressor/cytotoxic cells are increased in number in the peripheral blood during active infectious mononucleosis and are responsible for the control of EBV infected lymphocytes in seropositive subjects. ${ }^{22}$ Recently, however, EBV specific cytotoxic $T$ inducer cells have been identified ${ }^{23}$; the splenic lymphocytes may represent residual normal populations, although similar cells within the hepatic infiltrates could indicate a specific antiviral response. Conversely, the paucity of $\mathrm{T}$ suppressor/cytotoxic cells in the tissues may be a reflection of increased requirements in the periphery. As one of the underlying defects in XLPS has been suggested to be inadequate generation of EBV specific suppressor/cytotoxic T cells, however, a similar defect in this patient cannot be excluded.

We thank the Department of Virology, St George's Hospital Medical School, for help with EBV serology on the patient.

\section{References}

1 Sixbey JW, Pagano JS. New perspectives on the Epstein-Barr virus in the pathogenesis of lymphoproliferative disorders. Current Clinical Topics in Infectious Diseases 1984;5:146-74.

2 Purtilo DT, Sakamoto K, Saemundsen AK, et al. Documentation of Epstein-Barr virus infection immunodeficient patients with life-threatening lymphoproliferative diseases by clinical, virological and immunopathological studies. Cancer Res 1981;41:4226-36.

3 Purtilo DT. Immunopathology of $x$-linked lymphoproliferative syndrome. Immunology Today 1983;4:291-7.

4 Ando I, Morgan G, Levinsky RJ, Crawford DH. A family study of the $\mathrm{x}$-linked lymphoproliferative syndrome: evidence for a B cell defect contributing to the immunodeficiency. Clin Exp $J$ Immunol 1986;63:271-9.

5 Thomas JA, Iliescu V, Crawford DH, Ellouz R, Cammoun M, de The G. Expression of HLA-DR antigens in nasopharyngeal carcinoma: an immunohistological analysis of the tumour cells and infiltrating lymphocytes. Int J Cancer 1984;33:813-9.

6 Uchiyama T, Broder S, Waldmann TA. A monoclonal antibody (anti-Tac) reactive with activated and functionally mature human T cells. I. Production of anti-Tac monoclonal antibody and distribution of TAC $(+)$ cells. J Immunol 1981;126: 1393-7.

7 Epenetos AA, Bobrow LG, Adams TE, Collins CM, Isaacson PG, Bodmer WF. A monoclonal antibody that detects HLA-D region antigen in routinely fixed, wax embedded sections of normal and neoplastic lymphoid tissues. $J$ Clin Pathol 1985;38:12-17

8 Haynes BF. Summary of T cell studies performed during the second international workshop and conference on human leukocyte differentiation antigens. In: Reinherz EL, Haynes BF, Nadler LM, Bernstein ID, eds. Leucocyte typing II. Vol 1 . Human T lymphocytes. New York: Springer Verlag, 1986:3-30.

9 Mason DY, Abdulaziz Z, Falini B, Stein H. Double immunoenzymatic labelling. In: Polak JM, Van Noordan S, eds. Immunocytochemistry. Practical applications in pathology and biology. Bristol: Wright PSG, 1983:113-28.

$10 \mathrm{Hsu}$ S, Jaffe ES. Phenotypic expression of B-lymphocytes. Am J Pathol 1984;114:387-95.

11 Krajewski AS, Guy K, Dewar AE, Cossar D. Immunohistochemical analysis of human MHC Class II antigens in B-cell non-Hodgkin's lymphomas. J Pathol 1985;145:185-94.

12 Balkwill FR. The regulatory role of interferons in the human immune response. In: Taylor-Papadimitriou J, ed. Interferons. Their impact in biology and medicine. Oxford: Oxford University Press, 1981:61-80.

13 Balkwill FR, Stevens MH, Griffin DB, Thomas JA, Bodmer J Interferon gamma regulates HLA-D expression on solid tumours in vivo. Europ $J$ Cancer (In press).

14 Shearer WT, Ritz J, Finegold MJ, et al. Epstein-Barr virusassociated B-cell proliferations of diverse clonal origins after bone marrow transplantation in a 12-year-old patient with severe combined immunodeficiency. New Engl J Med 1985; 312:1151-9.

15 Hanto DW, Frizzera G, Gajl-Peczalska KJ, et al. Epstein-Barr virus-induced B-cell lymphoma after renal transplantation. New Engl J Med 1982;306:913-18.

16 Saemundsen AK, Klein G, Cleary M, Warnke R. Epstein-Barrvirus-carrying lymphoma in cardiac transplant recipient. Lancet 1982;ii: 158.

17 Ziegler JL, Miner RC, Rosenbaum E, et al. Outbreak of Burkitt's like lymphoma in homosexual men. Lancet 1982;ii:631-3.

18 Crawford DH, Epstein MA, Achong BG, et al. Virological and immunological studies on a fatal case of infectious mononucleosis. $J$ Infect 1979;1:37-48.

19 Robinson JE, Brown N, Andiman W, et al. Diffuse polyclonal B-cell lymphoma during primary infection with Epstein-Barr virus. New Engl J Med 1980;302:1293-7.

20 Sullivan JL, Medveczky P, Forman SJ, Baker SM, Monroe JE, Mulder C. Epstein-Barr virus induced lymphoproliferation. New Engl J Med 1984;311:1163-7.

21 Cleary ML, Sklar J. Lymphoproliferative disorders in cardiac transplant recipients are multiclonal lymphomas. Lancet 1984;ii:489-93.

22 Crawford DH, Edwards JMB. The Epstein-Barr virus. In: Zuckerman AJ, Pattison JR, Banatvala JE, eds. Principles and practice of clinical virology. Chichester: John Wylie, 1986.

23 Misko IS, Pope JH, Hutter R, Soszynski TD, Kane RG. HLADR-antigen-associated restriction of EBV-specific cytotoxic Tcell colonies. Int J Cancer 1984;33:239-43.

Request for reprints to: Dr P Morgan-Capner, Department of Virology, Pathology Laboratory, Preston Infirmary, Preston, Lancashire PR1 6PS, England. 